IZA DP No. 5214

Post-Socialist International Migration:

The Case of China-to-South Korea

Ethnic Labour Migration

Anna Myunghee Kim

September 2010 


\title{
Post-Socialist International Migration: The Case of China-to-South Korea Ethnic Labour Migration
}

\author{
Anna Myunghee Kim
}

IZA

\author{
Discussion Paper No. 5214 \\ September 2010
}

\author{
IZA \\ P.O. Box 7240 \\ 53072 Bonn \\ Germany \\ Phone: +49-228-3894-0 \\ Fax: +49-228-3894-180 \\ E-mail: iza@iza.org
}

\begin{abstract}
Any opinions expressed here are those of the author(s) and not those of IZA. Research published in this series may include views on policy, but the institute itself takes no institutional policy positions.

The Institute for the Study of Labor (IZA) in Bonn is a local and virtual international research center and a place of communication between science, politics and business. IZA is an independent nonprofit organization supported by Deutsche Post Foundation. The center is associated with the University of Bonn and offers a stimulating research environment through its international network, workshops and conferences, data service, project support, research visits and doctoral program. IZA engages in (i) original and internationally competitive research in all fields of labor economics, (ii) development of policy concepts, and (iii) dissemination of research results and concepts to the interested public.
\end{abstract}

IZA Discussion Papers often represent preliminary work and are circulated to encourage discussion. Citation of such a paper should account for its provisional character. A revised version may be available directly from the author. 


\section{ABSTRACT \\ Post-Socialist International Migration: The Case of China-to-South Korea Ethnic Labour Migration}

This paper examines an atypical south-north labour migration that emerged in the postsocialist international migration system: China-to-South Korea ethnic labour migration. In the past two decades, South Korea has experienced an unprecedented increase in the arrival of foreign labour. The majority of the low-skilled migrant workers come from the People's Republic of China. Based on a multivariate analysis of primary survey data on 525 predominantly undocumented Chinese migrants of Korean descent in Seoul, this study reveals the underexplored economic dimension of ethnic migration in Northeast Asia. Empirical findings on this source of migrant labour in South Korea demonstrate that the China-to-South Korea ethnic population movement is an important yet an unknown dimension of the New Economics of International Labour Migration. The study suggests that ethnic migration from a socialist transition economy to a capital-rich economy linked through ancestral connections must be (re)considered in the context of the changing global migration and demographic landscapes, rather than the ethno-nationally romanticised view of the return of diaspora.

JEL Classification: J6

Keywords: ethnic labour migration, post-socialist global migration regime, Northeast Asia, new economics of international labour migration

Corresponding author:

Anna Myunghee Kim

IZA

P.O. Box 7240

D-53072 Bonn

Germany

E-mail: akim@iza.org 


\section{Introduction}

What is widely known as ethnic migration or ethnic return migration involves ancestral homeward movement of the former expatriates or their descendants after a significant period of displacement. Most existing studies of these particular human migration dynamics have focused on exploring the historical and ethno-cultural landscapes of the diasporas. On the other hand, the economic landscape of ethnic migration exposes the growing significance of the particular labour - when and where ethnic populations relocate in the changing global capitalist system. The case of China-to-South Korea ethnic labour migration is an example of this pathway that remains poorly understood.

Since the diplomatic normalisation between the People's Republic of China and the Republic of Korea (South Korea) in 1992, about 200,000 Chinese of Korean descent known as "Chosunjok" in Korean had come to their capitalist ancestral homeland in less than ten years. By the early 2000s this ethnic migrant group established as a primary segment of the South Korean economy's low-wage workforce. Yet the economic dynamism of the co-ethnic migration between the two core economies of East Asia is virtually unknown in the literature of both international labour migration and the geography of capitalism.

\section{The Chosunjok Korean minority in China}

Today's Korean ethnic minority population of China - Chosunjok - mainly originated from massive wartime expatriation. In the time span from the Japanese occupation through World War II (the 1910s to 1940s), more than 2.5 million Koreans moved to Chinese Manchuria and Japan as activists for the independence movement and as wartime forced labour. Today, nearly 2 million descendants of the Korean expellees form one of the major ethnic minority citizen groups of the People's Republic of China. They currently make up about $0.2 \%$ of the total Chinese population. The Chosunjok Korean Chinese are concentrated in the Northeast 
provinces, mostly in Jilin (population 1,145,688 as of the year 2000), which includes the Yanbian Korean-autonomous prefecture. The other provinces are Heilongjiang $(388,458)$ and Liaoning $(241,052)$. This Korean minority population known as Chaoxianju $^{1}$ in Chinese are well-known to be the most educated minority population of the multiethnic socialist state, and they boast the highest literacy rate among all 56 ethnic minority populations of China (Yoon, 2000; Shih, 2000; Xizhe, 2000). Chosunjoks of China continued to have a close connection with North Koreans throughout the Cold War period through the communist brotherhood and an open cross-border movement between the two states. However, the Chosunjok Koreans had no access to South Korea until 1992.

Thus the distinction of Korean Chinese migration to the two states of the divided Korean peninsula - The Democratic People's Republic of Korea (North Korea) and The Republic of Korea (South Korea) - is important in this study both in terms of the political implications of cross-border movement and the identity of the different Korean communities.

The discussion of the Chosunjoks and the emerging international migration of the Korean minority from China is very limited in the existing literature. In the international migration literature and in the public, Chosunjoks are often recognised either as Chinese or Korean immigrants. This leaves out the complex background of the Korean Chinese diaspora community both in the PRC and in the Chosunjoks' new countries of settlement, which include South Korea. In the Korean literature, discourse of the Chosunjok migrants has been centred on the issues related to the 'law for overseas Koreans' and the identity politics of the Korean diaspora. A concentration of earlier public interest in the law for overseas Koreans is due to the constitutional controversy over return rights regarding the nationality of ethnic Koreans from China and the former Soviet Union that evolved with their increasing influx to South Korea in the post-socialist period. The pre-2003 revised legislation

\footnotetext{
${ }^{1}$ In China "Chaoxianju” distinctively refers to the Koreans of China and North Korea, while South Koreans are differentiated from the former ethnic Korean groups and known as "HanGuo-Ren”.
} 
disallowed visa-free entry for those extra-national Koreans travelling to South Korea if they had left the Korean peninsula before the foundation of the Republic of Korea (South Korea) in 1948. Consequently, consideration of the economic implications of Chosunjok Chinese migration has been much more limited in comparison to political concerns over the ethnic population movement.

Based upon the data of a primary survey carried out in 2003, this study explores the previously undocumented economic dimension of the post-1990 wave of ethnic migration from Northeast China to South Korea. In doing so, the study raises the following central questions: First, what are the underlying forces that propel the post1990 ethnic migration from China to South Korea? Second, what implications does the growing foreign labour migration influx to South Korea have for the Northeast Asian and international migration system?

\section{The new economics of ethnic migration}

A variety of theoretical approaches have been taken to explore what is broadly known as return migration. The most eminent studies of this type of international migration are found in post-Cold War European literature, which has more recently focused on the reintegration process of the former expatriates from the socialist East. While each study is based on different frames of reference, most of the analyses focus on addressing the political significances and implications of the European diaspora.

In Korean literature, despite the Chosunjok migrants' dominant de facto position as foreign labour migrants in South Korea, the economic dimension of the ethnic population movement remains underexplored. This largely owes to the same ethnicity of the migrant minority that is supposed to be considered in the return migration context rather than international labour migration. The same ethnicity demographic profile of the migrants has also been a source of myth and 
misinterpretation of the Chosunjok's de facto motivations and situatedness in the host country.

Da Vanzo's (1976) definitions of return and non-return migrations based on economic sensitivity in the migrant's decision making are particularly useful in understanding the post-socialist emerging ethnic migration. According to him, when it comes to non-pecuniary factors such as friends and relatives, return migration is more responsive than non-return or labour migration. Thus, it results in less information and more hidden costs in the return move than in the non-return move (Da Vanzo, 1976:15). This definition, though it is a simple analysis, provides an essential clue for understanding the emerging 'ethnic labour migration', from the putatively diasporic migrant communities living in a collective trauma, to a new type of diaspora of global labour involving immigrants seeking better opportunities.

This study attempts to explore the shrouded economic dimension of China-to-South Korea ethnic migration. Hypotheses are drawn and modified by key assumptions of the New Economics of International Labour Migration (NEILM), which test the underlying macro- and micro-level factors of economic decision-making of the ethnic labour migrants. While the neo-classical model of international migration views absolute wage differences as the most powerful determining factor of the individual's would-be permanent migration, international migration within the AsianPacific migration system is predominantly a household-level decision within a 'family-migration system' (Root and De Jong 1991 et al. Boyle et al. 2003). This is particularly prevalent in the Northeast Asian context of migration. Most cross-border migrations in this Confucian culture-dominant region are chosen as a strategy to increase the effective savings of the household, where investment in the wellbeing of the family, especially the education of children (Hugo 1998 et al. Hugo 1992, Massey 1987, Cases 1985), is the highest priority. Such cross-border migration is strongly motivated by the household's desire to improve its income position relative to others in the household's reference group (Stark, Taylor 1989). This has been 
prevailing in post-reform China as well. As many have argued (Massey et al 1998), for those households struggling to cope with the harsh transformations of the capitalist development, foreign migration has become one of the most powerful means of overcoming market failures and widening the family's access to resources.

The mass migration of the ethnic Korean population from the post-reform economy of Northeast China to South Korea exemplifies this principal tendency well. Most of the Chosunjok migrants are parents who are devoted to the education of their children in the emerging Chinese economy. They have been induced to undertake temporary labour migration to meet the rising demands of the household unit, along with higher education expenditures for their children as a primary disbursement.

In line with the new economic view, the study assumes that the ethnic labour migrants are "target earners" (Constant, Massey, 2002), who aim to do whatever temporary paid labour is available in the capital-surplus country at the expense of the individual migrant's social status and cultural alienation in the country of destination. Despite the possibility of becoming permanent settlers as suggested by the cumulative causation theory of international labour migration, the Chosunjok migrants do wish and intend to return home when such household-level financial demands are either no longer critical or have been satisfactorily met. In general, for such target earners, selection of migration in relation to their human capital is relatively unimportant.

Most of the temporary labour migrants endure lower socio-economic status in the host society than they had or could have had in their home country. The new economic perspective of migration postulates that upholding social prestige is irrelevant to one's foreign labour. Those Chosunjok migrants who were formerly white-collar workers, such as teachers and doctors at home in Northeast provinces of 
China, have readily accepted low status, labour-intensive jobs like childcare, waitressing and construction work upon arrival in their capitalist ancestral homeland.

Despite the expected risk and high cost of illegal migration, labour in the South Korean service industry is seen as an inevitable option for most of the Chosunjok families in Northeast China. The opportunity cost of labour migration to South Korea is generally believed to be high. For those average Chosunjok people, temporary labour migration to South Korea is considered to provide lucrative opportunities, either to accumulate the capital that the Chosunjok migrant's family needs in China, or to open a fast channel of overseas migration through which the family members can move out of the poverty at home in China.

Models in this study are mainly designed to identify the extent to which the volume and behaviour, i.e. mode of entry and legal status, of the ethnic labor migrants from the less developed country to the more developed ethnic home country in East Asia, is driven by particular socio-economic and political circumstances of both the sending and receiving countries. Considering the economic dimension of the ethnic migration is critical to ultimately understand the underlying motivations and ambitions of the Chosunjok Korean-Chinese migrants.

Ethnic labour migration from Northeast China to South Korea is further considered under "time-specific dynamics". This study takes the mid-1990's into consideration, dividing this period into the years before 1995 and from 1995 onward. The mid1990's has been chosen as a politically and economically influential variable in the context of both the sending and receiving countries of the migration.

In the Chinese context, what is known as "internal reform policies" (IOM 2003), which were undertaken by the central government amidst the socialist state's intense marketisation in the mid-1990s, created an incentive for substantial emigration, 
particularly from the former State Owned Enterprises (SOE) industry concentrated in the Northeast provinces. It is argued that a historic turning point in post-socialist China's economy came in 1996, when the national economy crossed the structural threshold from a chronic shortage economy punctuated by inflationary cycles, to an oversupply economy mired in deflationary pressures (Lin, 2003:14). In particular, privatisation of the SOEs and lay-offs of state workers began to occur on a large scale in 1995 (Qian, 1999). That situation is considered to have had a significant impact on the living conditions of people in the Northeast region. It has been reported that by the end of 1996, up to 70 percent of small SOEs had been privatized in those traditionally SOE concentrated Northeast provinces. This resulted in about ten million lay-offs from the SOEs and an additional 11.5 million lay-offs in 1997 (Qian 1999:21).

The rising protests of tens of thousands of workers from the formerly state-owned mining industry, claiming overdue wages and new reforms designed to save the fading economy of the Northeast, demonstrate the deteriorating socio-economic conditions. These were also manifested in the increasing geographical inequalities which have emerged since marketisation. Reforms of the economy have radically restructured the geographical and social patterns of China. In crude terms, the growing regional, local and intra-provincial disparity (Wei and Ye 2004) is often referred as the 'coast-interior gap'.

The greatest polarisation has been observed between the provinces of the interior which include the former state-owned heavy industry economies of north-east (the Chosunjok heartland) and Beijing; and the Special Economic provinces of the southeastern coastal region including Shanghai, Guangdong, Fujian, Jiangsu and Sangdong. In terms of growth rate, development in the interior provinces has been much slower than those of the coastal regions. According to Brooks and Tao (2003), while the urban unemployment rate during 1990-2001 in Beijing ranged from 1.2 percent to 4.7 percent, unemployment rates in the peripheral Northeast provinces, 
notably Liaoning, Jilin and Heilongjiang have been estimated at $8.9 \%, 7.5 \%$ and $8.4 \%$ respectively, rates far higher than the national average of 5.6 percent during the same period.

It is argued that the shifting political economies and the massive re-structuring of the nation's socio-economic system has not only widened income disparity in the absolute sense, but also deepened social divisions (Fan 1995, Wei \& Ma 1996: Zhao\& Zhang 1999 in Wei \& Ye 2003). The massive internal and international displacement of labour from the waning regional and deprived rural economies of the country to both the capital-rich coastal regions and foreign countries is considered to be one major consequence of the uneven development.

Yet the lack of official and systematic aggregate data on the regional and interprovincial disparity of the post-reform socialist state has made it difficult to identify the wide range of problems that are faced by the people of China in different regions (Wang and Zhang et al., 2003; Wei and Ye, 2004).

In the Korean context, the mid-1990s have a number of important implications that could well permeate the experiences of both legal and illegal Chinese and Chinese of Korean descent migrant workers, as well as other foreign labourers who were absorbed by its industries. A recent study by the Korean Labour Institute shows that the South Korean labour market for the so-called 3-D (Dangerous, Dirty and [physically] Demanding) industries reached equilibrium in 1995 for the first time since the shortage of manual labour began in the late 1980s.

The supply of unskilled manpower was expanded via the 'trainee system' promoted by the state throughout the early 1990s. The post-1995 period also has political significance in determining whether the large influx of foreign labour would flourish. An immigration system that was unique to South Korea and Japan was the guest worker policy. Until the early 2000s this had been the only 'official' route of entry for unskilled foreign labour. The trainee system in Korea was introduced in 1992 with an initial quota of 10,000 workers and was officially instituted in 1994. It is 
widely believed that until the early 1990s, when such regulations were implemented, about 10,000 informal migrant workers had been tacitly utilised in the Korean 3-D industries. Official import of foreign labour escalated in 1995 with the enactment of a new policy called the 'guidelines for protection and management of foreign trainees'. More recent changes include new systems that have been implemented to further facilitate the access of foreign labour into the Korean economy's both lowand skilled labour-starved industries (Table 3).

From 1995 onward, the government gradually enlarged the annual quota of foreign labour admissions from less than 40,000 up to a maximum of 80,000 (Figure 1).

Figure 1 Growth of documented and undocumented foreign labour 1992-2000

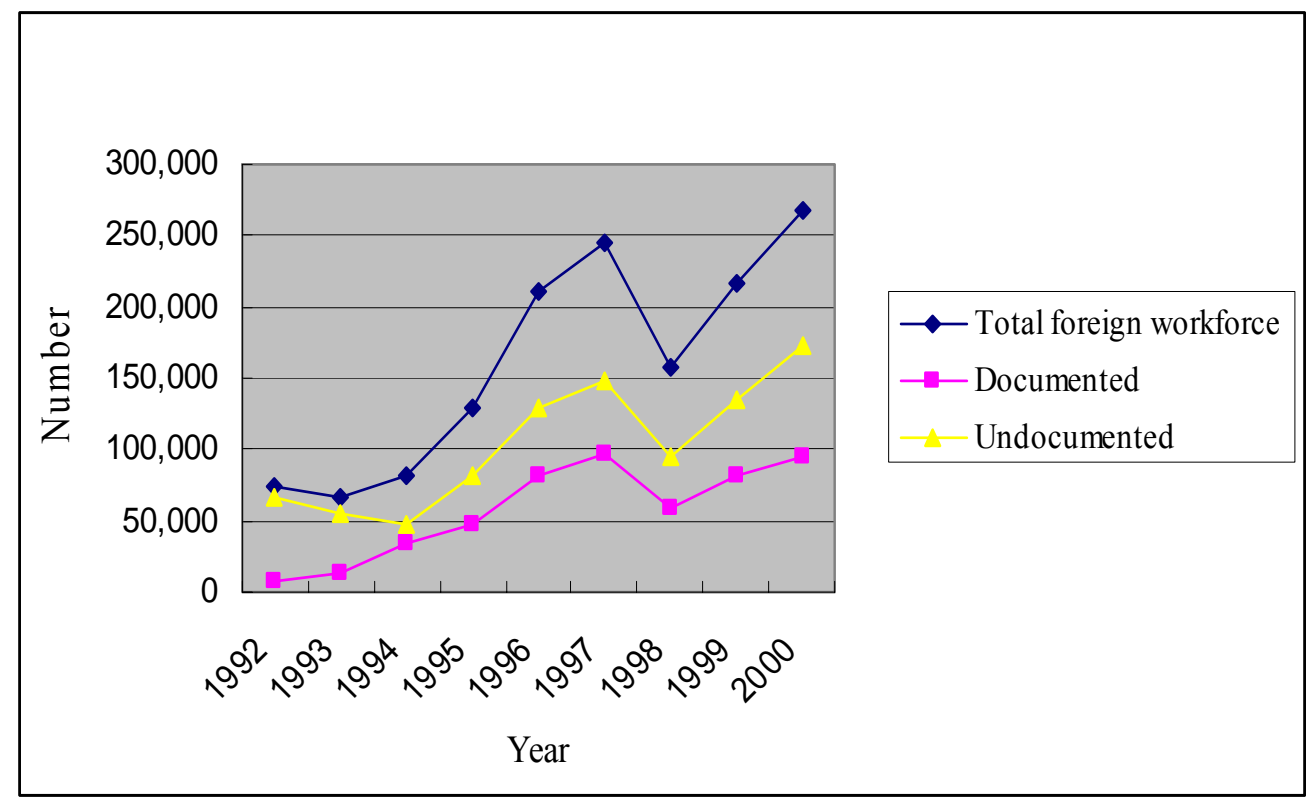

Source: OECD (2001b) et al Ministry of Justice (2000)

The sectors in which foreign trainees were allowed to work also expanded from merely the manufacturing industry to agricultural, service and other small-scale, labour-short sectors. Between 1995 and 1996, another 50,000 foreign labourers were accepted under the revised regulations of the foreign trainee system. According to a 
recent statistical report on the number of foreign trainees by nationality, Chinese make up the largest population $(23,254)$, of which over half are of Korean descent. This is estimated at 16,388, among a total 78,612 foreign trainees (Korean Federation of Small \& Medium Business 2001 et al. Korea Labour Institute, 2001). These political conditions and policy changes are considered to have played a significant role in intensifying the influx of labour from Northeast China in the mid-1990s.

In order to examine the above mentioned economic dynamics of the ethnic population movement from Northeast China to Korea, the following propositions are formulated and tested:

Hypothesis 1: Emerging ethnic labour migration from China to Korea exemplifies the new economics of labour migration that is primarily driven by the relative deprivation of the minority community's households and their pursuit of higher capital accumulation in a foreign labour market.

Hypothesis 2: The post-1995 migration of the Chosunjok, in contrast to the movement in the pre-1995 period, is strongly determined by the household's rising demand for investment in human capital through the education of their children.

Hypothesis 3: Illegal migration (both by mode of entry and overstay) of the Chosunjok more likely applies to negatively selected migrants and to the post-1995 period than to those positively selected migrants and the pre-1995 period.

\section{Methods and data}

Given the predominantly illegal status of Chosunjok migrants, no clear population listing was available, and therefore no formal probability sample could be drawn from the study. Instead, alternative means of access were developed with the understanding that the generalisation of results is limited to the group observed.

The survey relied on a rather unconventional combination of various techniques. What is known as convenient cluster sampling, a method that combines a 
convenience sample and a cluster sampling design, generated the sample of respondents. Procedures linked to the former sampling strategy included purposive and site-sampling techniques that were facilitated during the action research (Checkland 1998) based in Guro-Gu, Seoul. The Guro district, which was the heart of urban shantytowns for native factory workers from 1960 to 1980, was established as the capital's ghetto for underprivileged Asians during the 1990s, particularly Chinese national migrant workers. It is widely alleged that the Guro and Guemcheon 'Gus included over 30,000 Chosunjok Korean-Chinese and another 20,000 Han Chinese migrants (Jung-Ang Daily paper 13 August 2001). 
Figure 2 Chinese Enclaves in Seoul Metropolitan City

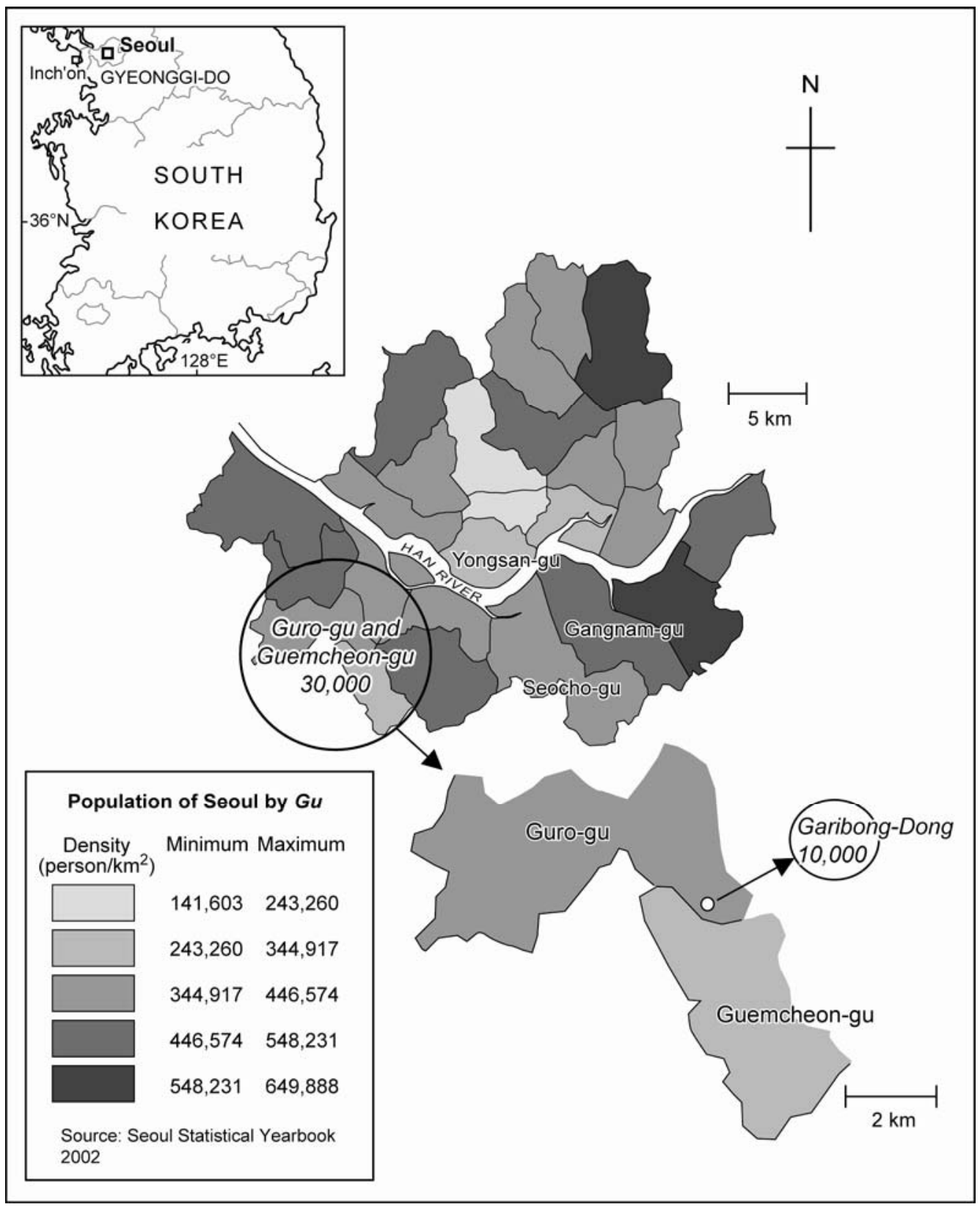

Sources: Seoul Statistical Yearbook 2002 and Jung-Ang Daily newspaper 13 August 2002 
The study areas included 27 percent of an estimated 110,000 Chosunjok migrants in the country, and provided a good locale for generating the cluster sampling. As stated earlier, the vast majority of the 525 surveyed in 2003 were illegal immigrants, either by mode of entry or over-stay.

\section{Table 1 Composition of the surveyed migrants by legal status}

\begin{tabular}{lcc}
\hline Total number of respondents & 525 & Percentage (100) \\
\hline $\begin{array}{l}\text { Legal by all means other than } \\
\text { naturalisation }\end{array}$ & 84 & $16 \%$ \\
*Legal by naturalisation & 42 & $8.0 \%$ \\
$\quad$ Illegal & $\mathbf{3 5 0}$ & $\mathbf{7 6} \%$ \\
\hline
\end{tabular}

*Among legals, naturalisation by marriage to a Korean citizen (usually Chosunjok women to South Korean men) was one of the primary methods of achieving legal status

About one-third of the respondents were involved in the Christian (church) organisation-based migrant communities and attended services regularly as an expression of their religious beliefs. Another third of respondents said they maintained contact with the migrant communities primarily to gather and exchange information about work and modifications in immigration regulations. Other reasons for having frequent contact with these humanitarian organisations and migrant communities included: help in finding jobs (2.1\%), meeting and making friends from home and to alleviate loneliness (7.7\%). Although not all respondents claimed this area was their pre-migration intended destination, more than three-quarters of respondents $(77.8 \%)$ said that South Korea was the top destination to go to for foreign labour. Thus, the logistic regression models estimated for this study focus on the socio-economic circumstances that influenced the 'labour migration' of Korean Chinese to Korea, relative to the circumstances of the migrants in the 1990s.

The data in the study were supplied by a sample of 525 Chosunjok migrants who live 
and work either formally or informally in South Korea on a temporary stay basis. Most of them were given temporary foreign resident status, such as C-3 (multiple purpose temporary/90-days stay) and D-3 (industrial trainee) on initial admittance to Korea. According to the Statistical Yearbook of Immigration Control in 2002, nearly $58 \%$ of the total documented Chosunjok migrants had entered South Korea on two of the visa types $(12,635$ with C-3 and 1,254 with D-4) instead of the F-1 visa $(1,553)$, which is specifically issued to extra-national Koreans for a temporary visit of their relatives in South Korea.

In order to ensure a consistent comparison of models, the logistic regression analysis of the study was completed using 371 valid cases in the sample, excluding blank responses in the database.

Because most of the migrants from China were extremely unfamiliar with and anxious about official surveys, the questionnaire was designed to collect qualitative information, an approach designed to improve the response rate. This categorical information is captured in sets of dichotomous variables. The nature of the Chosunjok's migration is divided by 'economic' (economically determined migration) and 'non-economic' (non-economically determined migration) motivations. The basic response variables are composed of a set of three dummy variables: 'economic and non-economic', 'pre-1995 and post-1995(1995 onward) migration,' and 'legal and illegal status of immigration'.

Migration to South Korea is used as a key response variable for the models of the various hypotheses. The dependent variable is defined as economically-determined migration (labour migration) that is primarily motivated by the desire to save enough money in order to cover the education fees of their children. In contrast, the nonpecuniary motivations for migration (non-economic migration) include: a nostalgia toward the motherland Korea \& visiting (blood) relatives (14.2\%); curiosity about the ancestral home country and migration of friends/neighbours in China (10.4\%); 
application for Korean citizenship to reclaim pre-1948 Korean nationality (3.4\%); marriage to a Korean (6.2\%); study (2.4\%); and other reasons $(6.4 \%)$.

The key explanatory variables of the multivariate statistical analysis consist of a set of dummy variables (Table 2). In addition to the human capital and demographic variables such as age, sex, marital status, skill achievement, educational level, and wage difference required for testing the principal assumptions of labour migration, this study also includes more contextual variables such as family status, which is based upon whether or not the migrant has dependent children, type of school(s) attended, political party membership in China, and intended (i.e. initially planned) duration of their foreign labour stay in Korea. 
Table 2 Details of variables used in multiple analysis

\begin{tabular}{|c|c|}
\hline Names of variables & Reference categories \& scoring \\
\hline \multirow{2}{*}{$\begin{array}{l}\text { Migration to Korea-Xb4 (response } \\
\text { variable) }\end{array}$} & Economic migration $=1$ \\
\hline & Non-economic migration $=0$ \\
\hline \multirow{2}{*}{ Age at time of migration-Pre_xa1 } & Over 40 (with age $40+$ ) $=1$ \\
\hline & Under $40=0$ \\
\hline \multirow{2}{*}{ Gender-a2sex } & Female $=1$ \\
\hline & Male $=0$ \\
\hline \multirow{2}{*}{ Family status-Xa4 } & Have child(ren) to raise at home $=1$ \\
\hline & Have no child $=0$ \\
\hline \multirow{2}{*}{ Marital status-XXa4 } & Married =1 \\
\hline & Unmarried $/$ single $=0$ \\
\hline \multirow{2}{*}{ Level of education-Xa6 } & Less than secondary/high school $=1$ \\
\hline & More than secondary/high school education $=0$ \\
\hline \multirow{2}{*}{ Type of school(s) attended-Xa7 } & Korean minority school(s) only $=1$ \\
\hline & Both Han majority and Ethnic minority schools $=0$ \\
\hline \multirow{2}{*}{ Type of occupation at home in China-Xa8 } & Unskilled job $=1$ \\
\hline & Skilled job $=0$ \\
\hline \multirow{2}{*}{$\begin{array}{l}\text { Employment status at home in China- } \\
\text { XXa8unem }\end{array}$} & Unemployed $=1$ \\
\hline & Otherwise $=0$ \\
\hline \multirow{2}{*}{$\begin{array}{l}\text { Communist party membership in China- } \\
\text { Xa9 }\end{array}$} & $\begin{array}{l}\text { Non-member of the communist party or no } \\
\text { political interest }=1\end{array}$ \\
\hline & Communist party member $=0$ \\
\hline \multirow{2}{*}{$\begin{array}{l}\text { Intended duration of foreign labour stay in } \\
\text { Korea-Xb6intst }\end{array}$} & Temporary (target earning stay) $=1$ \\
\hline & Otherwise (permanent stay in mind $)=0$ \\
\hline Income difference-Xc6_Incd & $\begin{array}{l}\text { Higher at least } 2-5 \text { or more times than the } \\
\text { earning at home }=1 \\
\text { Otherwise }=0\end{array}$ \\
\hline Social (network) capital-Xb8SOC & $\begin{array}{l}\text { Having a interpersonal tie established prior to } \\
\text { migration to the destination country }=1 \\
\text { Otherwise }=0\end{array}$ \\
\hline
\end{tabular}

While the most common demographic profile of an international migrant is one of a young, single male, as suggested by the neoclassical economic interpretation of international labour migration, the respondents in this study present an atypical composition. Here, an older generation (age 40+) is used as the reference group. According to the Statistical Yearbook of Immigration Control, 2002, those aged 40 and over make up 63 percent of the total registered Chosunjok Korean Chinese migrants and 60 percent of 'self-reported' illegal Chosunjoks during the amnesty programme. Most of the second generation Chosunjoks have one or two children to 
whom they wish to offer college education. The study presumes that rising family expenditure on education in post-reform China is a key incentive for low status foreign labourers among second generation Chosunjok parents.

Evidence that the middle-aged demographic profile of the Chosunjok immigration is not simply an artefact of the South Korean government's earlier 'ageist' policy which gave preference to older people (i.e. first and second generations of Korean expellees) for the grant of temporary visas, comes from several sources: (1) The middle-aged demographic character of Korean Chinese migrant workers persisted even when the age restrictions had been dropped in South Korea; (2) The middle-age bias is also evident in other destination countries of Chosunjok migrants such as Japan, and more recently the US metropolitan areas like Los Angeles and New York City. Given the above situation, respondent's familial status was considered a key explanatory variable in addition to marital status.

The type of school(s) attended in China was included as an important human capital variable that demonstrated advantage in terms of both human and social capital in the source country.

Those educated only in the Korean national minority school are assumed to be the Chosunjok who have lived in a monolingual and more ethno-nationally bounded environment; one's socioeconomic network is more likely to be limited in the ethnic Korean enclave. These respondents are assumed to be more likely to choose to migrate to Korea. The others include the cases of the migrants who have been educated both in Han majority and ethnic Korean minority school(s) and are therefore bilingual; they are more likely to have a socioeconomic advantage or be more easily assimilated into the mainstream Han majority society and consequently better off in China.

Political party membership is added as one significant human capital measure of the migrant from the socialist state, China. The respondents who were non-communist party members or had no political interest at all are considered to have low human 
capital and are thus negatively selected migrants. Income difference that is the principal measure of the neoclassical economic theory of migration is also considered in the analysis.

As a test of the tendency towards 'target earning,' a key assumption of the new economic theory of ILM, respondents were asked to report their 'intended' duration of foreign labour and stay in Korea. The reference group are those who intended a temporary stay that would end 'upon reaching a set accumulation of savings'. The other respondents included those who had no time limitation in mind or those who intended a possible permanent stay before undertaking the migration.

The study assumes that virtually all legal and illegal Korean Chinese labour migrants transfer their migrant savings to their family members in China, either in the form of remittances or an informal money transfer as observed in the findings of the ethnographic survey of the target population. Ninety-nine percent of those surveyed declared that they send part of their earnings in Korea to their family members in China. Given the illegal immigration status of the vast majority of Chosunjok migrant workers in Korea, most of the migrants use informal and in-person methods of money transfer. This makes the official estimation of the volume and value of remittances of the migrant population difficult. Thus, while the rate and volume of remittance is typically considered for the test of macro-level economic developments in the country of origin, in the new economic models of migration, no remittancespecific variable has been included.

All of the key socio-demographic variables are further considered in post-1990s temporal dynamics. The massive influx of Korean Chinese labour did not immediately follow the post-war diplomatic normalisation that took place between the Republic Korea and the People's Republic of China in 1992. Rather, the inflow of ethnic migrants and of illegal immigrants from China sharply increased in the mid1990 s. For this reason, a variable that controlled pre-1995 migration versus post1995 migration was included. This temporal variable is used to examine how, or to 
what extent, the post-1990 temporal dynamics influence selected determinants of economic migration. However, the period of the Asia Pacific region's financial crisis that occurred between 1997 and 1998 has not been taken into account, since this event has apparently only resulted in a short-term structural change and thus is a minor influence on the patterns of unskilled labour migration. In the long run, the Asian crisis has affected long-term mobility trends in the Pacific Asian region as a whole (see Athukoralge, P, 1999 and Manning, C, 2000).

A spatial dimension, which considers differences in the migrant's place of origin in their home country, was not included in the model; only 0.6 percent of respondents were from outside the three Korean minority populations concentrated in the northeast provinces of China, namely, Jilin (50.6\%), Laoining (16.6\%) and Heilongjiang (32.2\%).

\section{Findings and discussion}

Information was collected in an attempt to represent the most important dimension of a priori variability, and to reflect variability in status-based and demographic characteristics. That being said, a descriptive statistical analysis was used to more effectively summarise the complex direct and indirect relationships previously hypothesised. Tests of statistical inference in the study do not therefore claim generalisation, but typicality of the case and internal validity (Massey 1987). Overall, as a measure of precision and reliability, the findings of the study can be used within a broader framework to discuss the relative strength of relationships and the substantive significance and implications of key findings.

The descriptive statistics of Table 3 show binary relationships between explanatory and responsive variables in the primary data of the survey (for example between marital status and Chosunjoks' economic migration). The frequency analysis 
provides some information on the socio-demographic background of the migrant group prior to obtaining more sophisticated results of multiple logistic regression analysis. This allows us to identify a set of potentially influencing factors (likelihood) of the Chosunjok community's post-1990 exodus to South Korea. This is illustrated in Table 5 and Table 9 of the Findings Section. 
Table 3 Descriptive Statistics of the survey sample for key socio-demographic variables

\begin{tabular}{|c|c|c|c|c|}
\hline \multirow{5}{*}{ Number of responses } & \multicolumn{4}{|c|}{ All Chosunjok migrants (total $\mathrm{N}=525$ ) } \\
\hline & \multicolumn{2}{|c|}{ Economic $(n=310)$} & \multicolumn{2}{|c|}{ Non-economic $(n=215)$} \\
\hline & \multicolumn{2}{|c|}{ Before 1995} & \multicolumn{2}{|c|}{1995 onward } \\
\hline & Economic & Non-economic & Economic & Non-economic \\
\hline & $\mathrm{N}=46(\%)$ & $\mathrm{n}=38(\%)$ & $\mathrm{n}=264(\%)$ & $\mathrm{n}=177(\%)$ \\
\hline \multicolumn{5}{|c|}{$\begin{array}{l}\text { Socio-demographic characteristics } \\
\text { Age }\end{array}$} \\
\hline $20-29$ & $0(0)$ & $1(2.6)$ & $9(3.4)$ & $29(16.4)$ \\
\hline $30-39$ & $6(13)$ & $8(21.1)$ & $37(14.0)$ & 30 (16.9) \\
\hline $40-49$ & $13(28.3)$ & $9(23.7)$ & $110(41.7)$ & $31(17.5)$ \\
\hline $50-59$ & $16(34.8)$ & $9(23.7)$ & $78(29.5)$ & $61(34.5)$ \\
\hline 60 or over & $7(15.2)$ & $9(23.7)$ & $24(9.1)$ & $22(12.4)$ \\
\hline \multicolumn{5}{|l|}{ Sex } \\
\hline Female & $19(41.3)$ & $23(60.5)$ & $145(54.9)$ & $103(58.2)$ \\
\hline Male & $22(47.8)$ & $13(34.2)$ & $105(39.8)$ & $69(39.0)$ \\
\hline \multicolumn{5}{|l|}{ Family status } \\
\hline Have child(ren) & $24(58.7)$ & $19(50.0)$ & $160(60.6)$ & $75(42.4)$ \\
\hline Have no child(ren) & $13(31.7)$ & $11(28.9)$ & $75(28.4)$ & $85(48.0)$ \\
\hline \multicolumn{5}{|l|}{ Marital status } \\
\hline Married & $27(58.7)$ & $22(57.9)$ & $187(70.8)$ & $106(59.9)$ \\
\hline Unmarried & $8(17.4)$ & $7(18.4)$ & $43(16.3)$ & $46(26.0)$ \\
\hline \multicolumn{5}{|l|}{ Education } \\
\hline More than secondary/high school & $6(13)$ & $5(13.2)$ & $17(6.4)$ & $29(16.4)$ \\
\hline Less than secondary/high school & $40(80.7)$ & $33(86.8)$ & $247(93.6)$ & $148(83.6)$ \\
\hline \multicolumn{5}{|l|}{ Type of school(s) attended } \\
\hline Korean minority school(s) only & $33(71.7)$ & $22(57.9)$ & 181(68.6) & $111(62.7)$ \\
\hline $\begin{array}{l}\text { Both Han majority and Ethnic } \\
\text { minority schools }\end{array}$ & $6(13)$ & $12(31.6)$ & $67(25.4)$ & $56(31.6)$ \\
\hline \multicolumn{5}{|l|}{ Occupation at home (in China) } \\
\hline Unskilled (manual) & $29(63)$ & $15(39.5)$ & $138(52.3)$ & $101(57.1)$ \\
\hline Skilled (non-manual) & $14(30.4)$ & $19(50.0)$ & $117(44.3)$ & $73(41.2)$ \\
\hline \multicolumn{5}{|l|}{ Employment status in China } \\
\hline Unemployed & $2(4.3)$ & $2(5.3)$ & $17(6.4)$ & $6(3.4)$ \\
\hline Employed & $41(89.1)$ & $32(84.2)$ & $238(90.2)$ & $168(94.9)$ \\
\hline \multicolumn{5}{|l|}{ Current occupation (in Korea) } \\
\hline Unskilled & $42(91.3)$ & $25(65.8)$ & $239(90.5)$ & $146(82.5)$ \\
\hline Semi-skilled \& skilled & $4(8.7)$ & $13(34.2)$ & $25(9.5)$ & $31(17.5)$ \\
\hline \multicolumn{5}{|l|}{$\begin{array}{l}\text { Political party membership in } \\
\text { China }\end{array}$} \\
\hline $\begin{array}{l}\text { Communist party member } \& \text { pro- } \\
\text { state-socialism }\end{array}$ & $25(54.3)$ & $21(55.3)$ & 155 (58.7) & 79 (44.6) \\
\hline $\begin{array}{l}\text { Non-communist party member or } \\
\text { no political interest }\end{array}$ & $21(45.7)$ & $17(44.7)$ & $109(41.3)$ & $98(55.4)$ \\
\hline
\end{tabular}




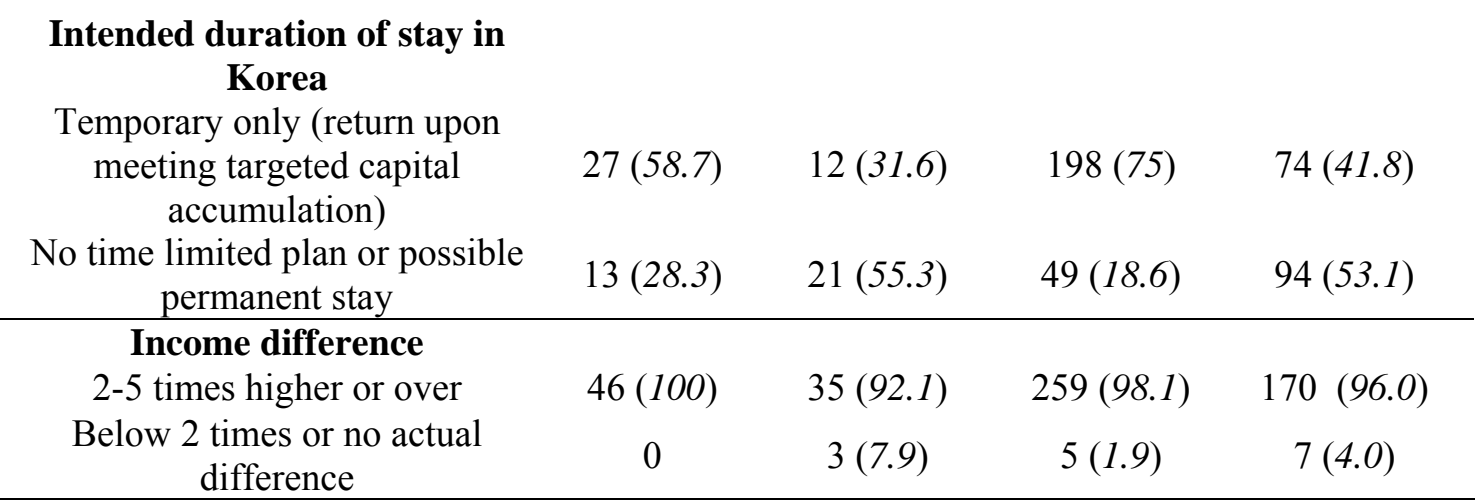

I define four key dimensions using the nature and timing of migration, namely economic (economically determined migration) versus non-economic (noneconomically determined migration) and before 1995 vs. from 1995 onwards. The larger volume of economic migration in the post-1995 time is clearly observable. There is a sharp increase of migration in the post-1995 time compared to the pre1995 time. In addition, I identify a difference in the age structure of the migrant flows of pre-1995 and post-1995; the inflow of young migrants between 20 and 39 was significantly larger during the latter period (Table 3 )

In the descriptive statistics of Table 3, it is interesting to notice that those who claimed to be non-economic migrants are characterised by a high proportion of respondents with incomes at least 2-5 times higher than in China; this pattern is apparent for migrants both in the pre-1995 period (92.1\%) and the post-1995 period $(96 \%)$ in South Korea. This indicates that most of the Chosunjok migrants are ultimately engaged in earning activities in the host country.

The chi-square analysis of Table 4 displays the simple relationships between all (without concerning the temporal and legal dimensions), economically-determined migration and key socio-demographic characteristics. 
Table 4 Chi-Square analysis of labour migration of Chosunjok in relation to key socio-demographic factors

\begin{tabular}{lcc}
\hline Age at time of migration & 8.809 & $\mathbf{0 . 0 0 3}$ \\
Sex & 3.118 & 0.528 \\
Family status & 11.838 & $\mathbf{0 . 0 0 1}$ \\
Marital status & 7.111 & $\mathbf{0 . 0 1 0}$ \\
Level of education & 14.018 & $\mathbf{0 . 0 0 0}$ \\
Type of (ethnic) school(s) attended in China & 4.753 & $\mathbf{0 . 0 3 5}$ \\
Type of occupation in China & 0.257 & 0.670 \\
Employment status in China & 1.955 & 0.240 \\
Communist party membership in China & 5.243 & $\mathbf{0 . 0 2 6}$ \\
Intended duration of stay in Korea & 71.839 & $\mathbf{0 . 0 0 0}$ \\
Income difference & 5.097 & $\mathbf{0 . 0 3 0}$ \\
Social network capital & 0.045 & 1.000 \\
\hline *N=371 & & \\
\hline
\end{tabular}

According to the chi-square significance test of Table 4, those who are older, married, have children at home, attended ethnic Korean schools only, have less education, no communist party membership, intend a temporary stay/foreign labour and expected and experienced at least 2-5 times higher incomes (earnings) are highly correlated to the economic migration of Chosunjok to Korea.

Interestingly, the chi-square analysis demonstrates that social capital (namely, having a migrant social network established prior to the move to Korea, which is widely deemed to be one of powerful forces of initial migration) has no strong association with the Chosunjok's migration to South Korea. In this survey, fewer than $12 \%$ of the total respondents said that they undertook their migration to Korea whilst primarily relying on the assistance of their social network. This can be explained in two ways: 1) immigration of the Chosunjok to Korea is so far only a decade-long phenomenon which began to flourish in the mid-1990s. Thus, interpersonal ties among Chosunjok migrants have not been strong enough to entice and sustain their foreign labour migration. 2) According to the preliminary survey in the study, motivation (and commitment) to build social networks among the mostly temporary Chosunjok labour migrants appears to be relatively weak. 
For example, of the migrants surveyed in response to questions about 'social life in Korea', 13 percent said they engaged in manual labour in excess of 10 hours per day and had no time to meet people or socialise, while 2.6 percent said they had no close friend(s) in Korea.

Indeed, both as individuals and as part of a group, the Chosunjok migrants tend to have a weaker solidarity compared to other minority populations in the host country. Upon comparison of this migrant group to South Asian labour migrant communities, such as Catholic Filipinos and Bangladeshi and Pakistani Muslim minority groups in the receiving society this becomes clear. South Asian migrants bond over similar social and religious ideas and tend to take more initiative to organise collective activities.

In general, the Chosunjok target-earning migrants from the socialist state of China have no strong religious background and tend to value community activities to a lesser degree. According to the study's ethnographic observation, this social isolation appears to be more dominant among those Chosunjok labourers who hail from whitecollar backgrounds in China. Preserving their self-esteem is quite important for most hard working Chosunjok migrant labourers who earn their livings through low-status and low-wage jobs. Primarily, this constitutes the concealment of their low-skilled and low-class status from others in the host society, particularly from those who originate from their heartland - the Northeast Chinese provinces.

On the other hand, the majority of the Chosunjok migrant workers found it far easier to get along with people from China than with native South Koreans. Overall, both survey findings and ethnographic observations of the analysis population attest that the majority of Chosunjoks in South Korea are highly goal-oriented, target earning and individualistic.

The logistic regression analysis of Table 5 shows the likelihood of economic migration of Korean Chinese in relation to selected human capital variables without controls for year and a legal status of immigration. 
Table 5 Logistic Regression models for key features and likelihood of labour migration of Chosunjoks to South Korea

\begin{tabular}{|c|c|c|c|c|c|c|c|c|c|c|c|c|}
\hline \multirow{3}{*}{ Explanatory variables } & \multicolumn{12}{|c|}{$\begin{array}{c}\text { Response variable } \\
\text { Economic Migration of Chosunjok to Korea }(n=371)\end{array}$} \\
\hline & \multicolumn{3}{|c|}{ Model A } & \multicolumn{3}{|c|}{ Model B } & \multicolumn{3}{|c|}{ Model C } & \multicolumn{3}{|c|}{ Model D } \\
\hline & $\mathrm{B}$ & sig. & $\operatorname{Exp}(B)$ & $\mathrm{B}$ & sig. & $\operatorname{Exp}(B)$ & $\mathrm{B}$ & sig. & $\operatorname{Exp}(B)$ & $\mathrm{B}$ & sig. & $\operatorname{Exp}(\mathrm{B})$ \\
\hline Age at time of migration & 0.362 & 0.183 & 1.436 & 0.365 & 0.173 & 1.441 & & & & 0.513 & 0.046 & 1.670 \\
\hline Family status & 0.661 & 0.076 & 1.937 & 0.675 & 0.066 & 1.964 & 0.748 & 0.003 & 2.113 & - & - & \\
\hline Marital status & 0.008 & 0.985 & 1.008 & -0.034 & 0.934 & 0.967 & - & - & & 0.612 & 0.031 & 1.844 \\
\hline Level of education & 1.298 & 0.001 & 3.662 & 1.203 & 0.001 & 3.330 & 1.269 & 0.000 & 3.557 & - & - & \\
\hline Type of school(s) attended in China & 0.296 & 0.294 & 1.344 & 0.267 & 0.337 & 1.306 & & & & - & - & \\
\hline Type of occupation in China & -0.161 & 0.544 & 0.851 & - & - & & - & - & & - & - & \\
\hline $\begin{array}{l}\text { Employment status at home in } \\
\text { China }\end{array}$ & - & - & & - & - & & - & - & & 1.089 & 0.074 & 2.971 \\
\hline $\begin{array}{l}\text { Political party membership in } \\
\text { China }\end{array}$ & -0.386 & 0.137 & 0.680 & -0.356 & 0.165 & 0.700 & - & - & & - & - & \\
\hline Intended duration of stay & 1.909 & 0.000 & 6.746 & 1.928 & 0.000 & 6.876 & 1.954 & 0.000 & 7.057 & 1.948 & 0.000 & 7.015 \\
\hline Income difference & 1.516 & 0.063 & 4.554 & - & - & & & & & 1.373 & 0.074 & 3.947 \\
\hline Constant & -3.927 & 0.000 & & -2.446 & 0.000 & & -2.357 & 0.000 & & -5.134 & 0.001 & \\
\hline Estimated Odds & 1.633 & & & 1.634 & & & 1.617 & & & 0.310 & & \\
\hline Hosmer and Lemeshow Test & 11.308 & 0.185 & & 12.286 & 0.139 & & 6.468 & 0.263 & & 8.866 & 0.181 & \\
\hline -2 Log likelihood & 394.901 & & & 399.112 & & & 405.296 & & & 409.572 & & \\
\hline Cox \& Snell R-Square & 0.245 & & & 0.236 & & & 0.223 & & & 0.214 & & \\
\hline Model Chi-square & 104.148 & 0.000 & & 99.937 & 0.000 & & 93.752 & 0.000 & & 89.476 & 0.000 & \\
\hline
\end{tabular}


Model A is the reference category tested with all hypothesised correlated variables, which include age at time of migration, family status, level of education, type of school(s) attended, type of occupation in China, Communist party membership, intended duration of stay in Korea and income difference. Model B was sequentially tested with the variables that showed significant correlation to the dependent variable in the first chi-square analysis of the data (Table 5). Testing of the exploratory Model $\mathrm{C}$ includes only the variables with a high p-value - namely family status as measured by having children at home, lower education, and intention of temporary foreign labour stay overseas (i.e., S. Korea) - and were entered using stepwise method. Model $\mathrm{C}$ appears to provide microeconomic level decision making characterisation of the likelihood of labour migration of Chosunjok. It shows that while having children to raise at home and lower educational achievements have positive correlation and strong influences on the economic migration of Chosunjok to Korea, intention to stay on a temporary visa indicates the strongest influence on the labour migration of the migrant group.

Model D is tested with theoretically powerful explanatory variables only. Drawn from both neoclassical economics and new economics of migration, these variables include age (younger), marital status (single), and employment status (unemployed), and intended duration of foreign labour stay (temporary) and income difference.

The prediction equation formula for the reference model category of hypothesis I (all cases) can be presented as:

Odds $($ economic migration $)=$

$$
\begin{aligned}
& e^{\beta_{0}}+\beta_{1} \text { pre } \_ \text {xal }(1)+\beta_{2} X a 4(1)+\beta_{3} X X a 4(1)+\beta_{4} X a 6(1)+\beta_{5} X a 7(1)+\beta_{6} X a 8(1)+\beta_{7} X X a 8 u n e m(1) \\
& +\beta_{8} X a 9(1)+\beta_{9} X b 6 \text { int st(1)+ } \beta_{10} X c 6 \_ \text {Incd (1) }
\end{aligned}
$$


While some variables included in model A, B and D do not suggest significance, odds of the model A, B. C show consistent outcome (all odds values are higher than 1), indicating the likelihood of economic migration being higher than noneconomically determined migration in relation to the selected explanatory variables. This confirms that hypothesis I is accepted within the 371 valid cases of the study sample, subject to the factors with which this hypothesis is concerned.

The chi-square significance test in Table 6 shows a correlation of key sociodemographic and economic factors to labour migration of Chosunjoks in the pre1995 and post-1995 periods 
Table 6 Chi-Square analysis of Chosunjoks' labour migration in the pre-1995 and the post-1995 periods

\begin{tabular}{|c|c|c|c|c|}
\hline \multirow{2}{*}{ Independent variables } & \multicolumn{2}{|c|}{ Before $1995(n=43)$} & \multicolumn{2}{|c|}{ From 1995 onward $(n=328)$} \\
\hline & $\chi^{2}$ & Sig.(2-tailed) & $\chi^{2}$ & Sig.(2-tailed) \\
\hline Age at time of migration & 0.512 & 0.547 & 8.224 & 0.005 \\
\hline Sex & 3.249 & 0.197 & 1.728 & 0.421 \\
\hline Family status & 0.705 & 0.509 & 11.538 & 0.001 \\
\hline Marital status & 0.179 & 0.728 & 7.251 & 0.009 \\
\hline Level of education & 0.179 & 0.728 & 15.244 & 0.000 \\
\hline Type of (ethnic) school(s) attended in China & 3.521 & 0.079 & 2.879 & 0.107 \\
\hline Type of occupation in China & 5.581 & 0.031 & 0.139 & 0.734 \\
\hline Employment status in China & 0.811 & 1.000 & 1.431 & 0.334 \\
\hline Political party membership in China & 0.029 & 1.000 & 6.270 & 0.013 \\
\hline Intended duration of stay in Korea & 12.352 & 0.001 & 59.451 & 0.000 \\
\hline Income difference & 4.074 & 0.079 & 1.845 & 0.271 \\
\hline Social network capital & 1.547 & 0.214 & 0.187 & 0.666 \\
\hline
\end{tabular}


According to the chi-square analysis in Table 6, only type of occupation (being unskilled) in China and intention of temporary stay are associated with labour migration at a significant level in pre-1995. In the post-1995 period, older age migrants, having children, being married, lower education, no communist party membership and intention of a temporary stay are all significantly correlated to economic migration of Korean Chinese. In both the pre-1995 and post-1995 periods, sex and 'unemployment' are not significantly correlated to the Korean Chinese population's economically determined migration.

A non-significant correlation of unemployment to economic migration may be due in part to the high rate of officially invisible and quasi-unemployed 'laid off' former employees of SOEs in the three Northeast Chinese provinces. In fact, currently in official statistics on national unemployment, the Chinese communist state does not include about 26 million total laid off workers. It is alleged that there are an estimated 15.2 million quasi-unemployed lay-offs in the Northeast provinces (China.org.cn December 28, 2003).

The logistic regression analysis shown in Table 7, controlling for year of migration, shows the overall difference (different influential factors) in the pre- and post-1995 periods of economic migrations of the Korean-Chinese population. The odds for Models A (reference category) and D (theory category) for each of the periods with the same explanatory variables show contrasting results. Whereas the odds of pre1995 migration are less than, the odds of the post-1995 migration are greater than 1. When controlling for the given factors, this difference indicates that post-1995 migration of Korean-Chinese is likely to be economic, while pre-1995 migration is likely to be non-economic.

In post-1995 migration, all models-except the theory testing Model D-show a positive correlation between new economic decision-making factors, such as having children to raise and the intention of (foreign labour) a temporary stay with labour migration of Korean-Chinese to Korea. Model C of post-1995 migration demonstrates the positive relation and strong influence of having children to raise, lower education, Communist Party membership and intention of staying in Korea temporarily on migration of Chosunjok during this period. 
Interestingly, in the survey sample, no Communist Party membership in China appears to correlate negatively to the economic migration of Chosunjok in Models A, B and C of post-1995 migration.

Conversely, this means that those ethnic Koreans who had Communist Party membership, and therefore tended to have a higher educational background as well as higher aspirations both for upward mobility and a good education for their children in the post-reform Chinese society, are more likely to migrate to South Korea in the post-1995 period. This underpins the key hypothesis of the new economics of labour migration (Stark, Taylor 1991), which proposes that the propensity of outward migration is not the highest among the poorest villages or local economies. Migration rates are higher from those areas or regions with an uneven level of development, that is, where the distribution of income is less equal and the reference group plays a significant role. Labour migration of the Chosunjok population from Northeast China which emerged in the post-1990 period, epitomises such a case. While the Chosunjok Korean Chinese community does not form the poorest social group in the local economy of China, their risky foreign labour migration is undertaken as a vital means of increasing their households' income compared to the relevant reference group.

Prediction equation for the reference model of HYP II (before 1995 \& 1995 onwards) is formulated as:

Odds (economic migration=yes $)=$

$$
e^{\beta_{0}}+\beta_{1} \text { pre } e_{-} x a 1+\beta_{2} X a 4+\beta_{3} X X a 4+\beta_{4} X a 6+\beta_{5} X a 7+\beta_{6} X a 8+\beta_{8} X a 9+\beta_{9} X b 6 \text { int } s t+\beta_{10} X c 6{ }_{-} \text {Incd }
$$


Table 7 Logistic regression model of pre-1995 time labour migration of Chosunjoks by selected key socio-economic and demographic characteristics

\begin{tabular}{|c|c|c|c|c|c|c|}
\hline \multirow{3}{*}{ Explanatory variables } & \multicolumn{6}{|c|}{ Pre-1995 labour migration of Chosunjok $(n=43)$} \\
\hline & \multicolumn{3}{|c|}{ Model A } & \multicolumn{3}{|c|}{ Model D } \\
\hline & $\mathrm{B}$ & sig. & $\operatorname{Exp}(B)$ & $\mathrm{B}$ & sig. & $\operatorname{Exp}(B)$ \\
\hline Age at time of migration & 0.752 & 0.493 & 2.121 & 0.799 & 0.336 & 2.223 \\
\hline Family status & 1.265 & 0.636 & 3.543 & - & - & - \\
\hline Marital status & 0.153 & 0.956 & 1.165 & 0.617 & 0.501 & 1.853 \\
\hline Level of education & 0.120 & 0.922 & 1.127 & - & - & - \\
\hline $\begin{array}{l}\text { Type of school(s) attended in } \\
\text { China }\end{array}$ & 0.621 & 0.603 & 1.861 & - & - & - \\
\hline Type of occupation in China & 1.372 & 0.245 & 3.943 & - & - & - \\
\hline $\begin{array}{l}\text { Employment status at home in } \\
\text { China }\end{array}$ & - & - & - & 22.405 & 1.000 & $5.375 \mathrm{E}+09$ \\
\hline $\begin{array}{l}\text { Political party membership in } \\
\text { China }\end{array}$ & 1.382 & 0.219 & 3.983 & - & - & - \\
\hline $\begin{array}{l}\text { Intended duration of stay in } \\
\text { S.Korea }\end{array}$ & 2.819 & 0.008 & 16.760 & 2.545 & 0.002 & 12.743 \\
\hline Income difference & 20.815 & 0.999 & $1.096 \mathrm{E}+09$ & 20.577 & 0.000 & $8.639 \mathrm{E}+08$ \\
\hline Constant & $83 . \overline{4}-$ & 0.999 & 0.000 & $11 \overline{-} \cdot 283$ & 0.999 & 0.000 \\
\hline${ }^{*}$ Estimated Odds & 0.458 & & & 0.588 & & \\
\hline Hosmer and Lemeshow Test & 4.149 & 0.843 & & 10.227 & 0.115 & \\
\hline-2 Log likelihood & 34.644 & & & 39.588 & & \\
\hline Cox \& Snell R-Square & 0.433 & & & 0.364 & & \\
\hline
\end{tabular}


Table 7 Continued

\begin{tabular}{|c|c|c|c|c|c|c|c|c|c|c|c|c|}
\hline \multirow{3}{*}{ Explanatory variables } & \multicolumn{12}{|c|}{ Post-1995 labour migration of Chosunjok $(n=328)$} \\
\hline & \multicolumn{3}{|c|}{ Model A } & \multicolumn{3}{|c|}{ Model B } & \multicolumn{3}{|c|}{ Model C } & \multicolumn{3}{|c|}{ Model D } \\
\hline & $\mathrm{B}$ & sig. & $\operatorname{Exp}(B)$ & $\mathrm{B}$ & sig. & $\operatorname{Exp}(B)$ & $\mathrm{B}$ & sig. & $\operatorname{Exp}(B)$ & $\mathrm{B}$ & sig. & $\operatorname{Exp}(B)$ \\
\hline Age at time of migration & 0.375 & 0.197 & 1.455 & 0.408 & 0.152 & 1.504 & - & - & & 0.518 & 0.057 & 1.679 \\
\hline Family status & 0.631 & 0.102 & 1.879 & 0.614 & 0.107 & 1.848 & 0.639 & 0.016 & 1.895 & - & - & - \\
\hline Marital status & -0.040 & 0.928 & 0.961 & -0.055 & 0.899 & 0.946 & - & - & - & 0.598 & 0.046 & 1.819 \\
\hline Level of education & 1.629 & 0.000 & 5.097 & 1.491 & 0.000 & 4.442 & 1.503 & 0.000 & 4.495 & - & - & - \\
\hline Type of school(s) attended in China & 0.155 & 0.604 & 1.168 & - & - & - & - & - & - & - & - & - \\
\hline Type of occupation in China & -0.338 & 0.232 & 0.713 & - & - & - & - & - & - & - & - & - \\
\hline Employment status at home in China & - & - & - & - & - & - & - & - & - & 0.915 & 0.135 & 2.496 \\
\hline Political party membership in China & -0.573 & 0.039 & 0.564 & -0.538 & 0.049 & 0.584 & -0.627 & 0.018 & 0.534 & & & \\
\hline Intended duration of stay in S.Korea & 1.855 & 0.000 & 6.390 & 1.857 & 0.000 & 6.404 & 1.866 & 0.000 & 6.462 & 1.893 & 0.000 & 6.636 \\
\hline Income difference & 1.295 & 0.137 & 0.026 & - & - & - & - & - & - & 1.076 & 0.197 & 2.932 \\
\hline Constant & -3.654 & 0.000 & 0.026 & -2.371 & 0.000 & 0.093 & -2.144 & 0.000 & 0.117 & & & \\
\hline *Estimated Odds & 1.686 & & & 1.679 & & & 1.281 & & & 1.651 & & \\
\hline Hosmer and Lemeshow Test & 16.288 & 0.038 & & 11.719 & 0.164 & & 3.548 & 0.616 & & 7.738 & 0.258 & \\
\hline-2 Log likelihood & 348.373 & & & 352.492 & & & 354.566 & & & 366.723 & & \\
\hline Cox \& Snell R-Square & 0.243 & & & 0.233 & & & 0.228 & & & 0.199 & & \\
\hline Model Chi-square & 91.277 & 0.000 & & 87.158 & 0.000 & & 85.084 & 0.000 & & 72.927 & 0.000 & \\
\hline
\end{tabular}


Table 8 shows associations between the basic human capital variables of the Chosunjok labour migrant pre-1995 and post-1995 according to legal status. In the case of the pre-1995 migrant once we control the year of migration, only two factors differ significantly according to their legal status: the temporary intention of stay and the difference in income. No other socio-demographic and economic factors are significantly associated with either illegal or legal labour migration pre-1995.

In the post-1995 period, political party membership and intended duration of stay are significantly associated with illegal labour migration of Korean Chinese. There is clear evidence for a larger volume of legally immigrating Chosunjok Korean Chinese aged over 40 in the post-1995 period, as shown in the descriptive statistics of the surveyed Chosunjok migrant population (Table 3). However, the results of the chisquare distribution analysis, as illustrated in Table 8, demonstrate a weak influence of the older age variable on the economically-determined migration of the Korean Chinese to South Korea, both in the pre-1995 and the post-1995 periods.

Detailed evidence for the minor role of the age variable and the age-specific policy in the sample population canvassed in 2003 is as follows. Firstly, the minimum age restriction has been dramatically reduced from 60 in the early 1990s, to 25 in 2003. Since 2000, the Korean government's policy on ethnic migrants from China and the former Soviet Union has been greatly liberalised.

Second, there has been remarkable development in the organisation of the illegal flow of Korean Chinese using forged documents. Korean authorities may have turned a blind eye to ambiguous visas because of the ways in which identity documents such as passports, family registration certificates and age of Korean Chinese have been professionally counterfeited. However, many have also simply gone undetected by officials. The prevalence of forged personal documents (often related to an ancestor's contribution to independence activities against the Japanese during the colonial regime, or of relatives in South Korea) is due to the priority for admittance and eligibility for naturalisation set by the Korean government. These circumstances further imply that although the earlier prioritised entry policy for older people (which continued through the mid-1990s) had facilitated the flow of older-generation Korean Chinese, the migration tendency of older Chosunjoks 
having children cannot be seen as a direct result of the government's age selection policy. The actual influence of the age preference policy on the large volume of older-age and illegal migration of Chosunjoks to South Korea is considered relatively minor.

On the other hand one must take note of the rapidly growing professional business of illegal immigration among both Chosunjok and Han Chinese communities, which has made 'pseudo-legal' China-to-Korea migration increasingly common. This remains to be another implicit raison d'être for a higher level of 'dejure' authorised migration of older generation Korean Chinese in comparison to younger and single migrants.

According to the primary survey, $1.8 \%$ of the total respondents said they smuggled themselves to South Korea, while $36.5 \%$ reported to have been de jure officially admitted to the country of destination by using manipulated passports and other documents. Paper falsification is commonly done through organised dealers in illegal cross-border migration in China. 
Table 8. Chi-Square analysis of economically determined migration to Korea in the pre-1995 and post-1995 periods of migration by legal status

\begin{tabular}{|c|c|c|c|c|c|c|c|c|}
\hline \multirow{4}{*}{ Independent variables } & \multicolumn{4}{|c|}{ Before $1995(n=43)$} & \multicolumn{4}{|c|}{ From 1995 onward $(n=328)$} \\
\hline & \multicolumn{4}{|c|}{ Mode of migration } & \multicolumn{4}{|c|}{ Mode of migration } \\
\hline & \multicolumn{2}{|c|}{ Illegal $(n=32)$} & \multicolumn{2}{|c|}{ Legal $(n=11)$} & \multicolumn{2}{|c|}{ Illegal $(n=251)$} & \multicolumn{2}{|c|}{ Legal $(n=77)$} \\
\hline & $\mathrm{X} 2$ & Sig.(2-tailed) & $\chi^{2}$ & Sig.(2-tailed) & $x^{2}$ & Sig.(2-tailed) & $\chi^{2}$ & Sig.(2-tailed) \\
\hline Age at time of migration & 0.349 & 0.703 & 0.637 & 1.000 & 0.508 & 0.548 & 5.975 & 0.018 \\
\hline Sex & 0.037 & 0.982 & 0.463 & 0.496 & 1.030 & 0.598 & 0.118 & 0.943 \\
\hline Family status & 0.518 & 0.683 & 0.917 & 0.564 & 2.154 & 0.182 & 3.694 & 0.067 \\
\hline Marital status & 0.194 & 1.000 & 0.543 & 1.000 & 3.081 & 0.098 & 2.781 & 0.080 \\
\hline Level of education & 0.015 & 1.000 & 0.196 & 1.000 & 4.222 & 0.073 & 4.146 & 0.056 \\
\hline $\begin{array}{l}\text { Type of (ethnic) school(s) attended in } \\
\text { China }\end{array}$ & 1.208 & 0.346 & 1.397 & 0.491 & 2.061 & 0.165 & 0.435 & 0.583 \\
\hline Type of occupation in China & 3.124 & 0.128 & 0.637 & 1.000 & 0.005 & 1.000 & 0.048 & 1.000 \\
\hline Employment status in China & - & - & 4.950 & 0.182 & 0.091 & 1.000 & 2.961 & 0.149 \\
\hline Political party membership in China & 0.276 & 0.712 & 0.020 & 1.000 & 3.919 & 0.051 & 2.306 & 0.186 \\
\hline Intended duration of stay & 9.349 & 0.005 & 0.637 & 1.000 & 29.170 & 0.000 & 15.281 & 0.000 \\
\hline Income difference & 4.693 & 0.091 & 0.244 & 1.000 & 4.373 & 0.070 & 1.456 & 0.253 \\
\hline Social network capital & 1.286 & 0.257 & - & - & 0.155 & 0.694 & 0.000 & 1.000 \\
\hline
\end{tabular}


The following determination is clear from the logistic regression analysis shown in Reference Model A of Table 9: While the criteria of having lower education and having attended only ethnic Korean school are positively related to illegal migration in the post-1995,period, the criteria of being unskilled and a non-Communist Party member at home in China are negatively related to post-1995 illegal migration..

Conversely, the latter statistical results indicate no positive association between negatively selected human capitals and illegal labour migration in the concerning period. My assumption regarding communist party membership (having noncommunist party membership as a low/negative human capital variable) is based upon the following argument: Those who are members of the communist party are likely to have stable socioeconomic status based on good social networks established through (and in) the state bureaucracy, and are therefore less likely to undertake risky and low-rewarding foreign labour than those from a sociopolitical background of non-communist party membership. However, in both the chi-square correlation analyses of Table 8 and the logistic regression analysis of Table 9 (see model C), the effect of having communist party membership on target earning economic migration of the Chosunjok appears to be strong.

These results remind of the prevailing market transition theory of Nee (1989), which argues that due to a shift from the state socialism's bureaucratic power control to the power of market institutions there is a negative effect of party membership in the marketised sector of the emerging urban economy. From this viewpoint, people who were privileged and better-off in pre-reform Chinese society are also likely to undertake risky and labour intensive international migration.

However, without further tests using more sophisticated sociopolitical variables, a true interpretation of the positive relationship between communist party membership and both the legal and illegal labour migration of Korean Chinese to Korea (and vice versa) remains tricky.

Prediction equation for the reference model of HYP III (Post-1995 and illegal) is: 
Odds $($ Economic Migration $=y e s)=$

$$
\begin{aligned}
& \mathrm{e}^{\beta} 0+\beta_{1} \text { pre_xa1(1) }+\beta_{2} \mathrm{Xa}_{-}(1)+\beta_{3} \mathrm{XXa}_{(1)}+\beta_{4} \mathrm{Xa}_{(1)}+\beta_{5} \mathrm{Xa}_{(1)}+\beta_{6} \mathrm{Xa}_{(1)} \\
& +\beta_{7} \operatorname{XXa8unem}(1 \quad)+\beta_{8} \operatorname{Xa9}(1)+\beta_{9} \operatorname{Xb6intst}(1 \quad)+\beta_{10} \operatorname{Xc6} \operatorname{Incd}(1 \quad)
\end{aligned}
$$


Table 9 Log likelihood of illegal labour migration of Chosunjok in the post-1995 migration in relation to selected explanatory variables

\begin{tabular}{|c|c|c|c|c|c|c|c|c|c|c|c|c|}
\hline \multirow{3}{*}{ Explanatory variables } & \multicolumn{12}{|c|}{$\begin{array}{c}\text { Response variable } \\
\text { Illegal economic migration of Chosunjoks in the post-1995 period }(\mathrm{n}=251)\end{array}$} \\
\hline & \multicolumn{3}{|c|}{ Model A } & \multicolumn{3}{|c|}{ Model B } & \multicolumn{3}{|c|}{ Model C } & \multicolumn{3}{|c|}{ Model D } \\
\hline & $\mathrm{B}$ & Sig. & $\operatorname{Exp}(B)$ & B & Sig. & $\operatorname{Exp}(B)$ & $\mathrm{B}$ & Sig. & $\operatorname{Exp}(B)$ & $\mathrm{B}$ & Sig. & $\operatorname{Exp}(B)$ \\
\hline Age at time of migration & 0.071 & 0.840 & 1.073 & - & - & - & - & - & - & 0.228 & 0.492 & 1.256 \\
\hline Family status & -0.603 & 0.285 & 0.547 & - & - & - & - & - & - & - & - & - \\
\hline Marital status & 1.078 & 0.080 & 2.938 & - & - & - & - & - & - & 0.608 & 0.086 & 1.836 \\
\hline Level of education & 0.896 & 0.098 & 2.450 & - & - & - & - & - & - & - & - & - \\
\hline Type of school(s) attended in China & 0.341 & 0.334 & 1.407 & - & - & - & - & - & - & - & - & - \\
\hline Type of occupation in China & -0.132 & 0.685 & 0.876 & - & - & - & - & - & - & - & - & - \\
\hline $\begin{array}{l}\text { Employment status at home in } \\
\text { China }\end{array}$ & - & - & - & - & - & - & - & - & - & 0.555 & 0.415 & 1.742 \\
\hline Political party membership in China & -0.634 & 0.054 & 0.530 & -0.602 & 0.046 & 0.547 & -0.602 & 0.046 & 0.547 & - & - & - \\
\hline $\begin{array}{l}\text { Intended duration of stay in } \\
\text { S.Korea }\end{array}$ & 1.725 & 0.000 & 5.613 & 1.618 & 0.000 & 5.041 & 1.618 & 0.000 & 5.041 & 1.635 & 0.000 & 5.127 \\
\hline Income difference & 2.504 & 0.049 & 12.232 & - & - & - & - & - & - & 2.106 & 0.090 & 8.212 \\
\hline Constant & -3.804 & 0.009 & 0.022 & 0.144 & 0.617 & 1.155 & 0.144 & 0.617 & 1.155 & -2.881 & 0.029 & 0.056 \\
\hline Estimated Odds & 2.968 & & & 2.836 & & & 2.836 & & & 1.123 & & \\
\hline Hosmer and Lemeshow Test & 7.313 & 0.503 & & 0.238 & 0.888 & & 0.238 & 0.888 & & 3.014 & 0.698 & \\
\hline -2 Log likelihood & 255.184 & & & 267.523 & & & 267.523 & & & 264.087 & & \\
\hline Cox \& Snell R-Square & 0.160 & & & 0.118 & & & 0.118 & & & 0.130 & & \\
\hline Model Chi-square & 43.828 & 0.000 & & 31.489 & 0.000 & & 31.489 & 0.000 & & 34.925 & 0.000 & \\
\hline
\end{tabular}


However, model $\mathrm{C}$ tested with those variables which have significant $\mathrm{p}$-value from the chisquared test results indicates the intention of a temporary stay (labour) as the strongest determinant of illegal labour migration among the Chosunjok post-1995. This therefore supports a new economic target-earning feature of illegal stays among Korean Chinese in the post-1995 period.

\section{Conclusion}

This study has attempted to reveal the much neglected economic dimension of the ethnic population movement from China to South Korea in an exploratory way.

Ethnic migration has been widely presumed to be a 'mythic return' responding to the call of the homeland. However, the multivariate models of this study underpin intertwined determinants of the new economics of ethnic migration at both macro and micro levels. Findings confirm that the Korean Chinese are not the traditionally dominant neo-classical economic migrants primarily seeking individual well-being. This is demonstrated in the dominant migration behaviour of Korean Chinese, who volunteer to undertake and endure low status, temporary labour in their capitalist ancestral country in order to meet the growing financial demands of the family in postreform China.

The analyses' findings on post-1995 migration of Korean Chinese to Korea show a strong association between movement and the regional post-reform economic restructuring in the origin economy of Northeast China. This is most notably seen to have affected the aspirational Korean Chinese families' rising capital demand for the education of their children. 
In particular, the strong association between older adults with children and the economically determined migration of Chosunjoks, demonstrated in chi-square analyses, attests to the Korean Chinese parents' strong commitment to the sound education of their children.

While commitment to educational achievement has traditionally been a dominant trait among Confucian East Asian nations, rising demand for higher education and targeting foreign labour of Chosunjoks post-1990 can be seen as a response to the structural change of the rapidly developing Chinese economy that increasingly seeks skilled labour.

Given the short history of Chosunjok Korean Chinese' migration, further investigation into the emerging global labour diaspora is required. More recently, there has been an increase in the flow of young Chosunjok students. They are seen as a key source of the highly sought after bilingual and skilled labour force from China which includes the engineers and business managers the global high-tech economy needs. Investigation into the emerging international skilled migration of the Chinese of Korean descent, and in particular implications of the movement for transnational development of Northeast China, remains a key agenda for future studies.

Finally, the findings remind us that the growing foreign labour migration to South Korea is interwoven with the increasing labour demand of the ageing South Korean economy. In the international development context, the Northeast China-to-South Korea population movement presents one of the atypical South-North migration movements observed in the new core tier of the global economy which was previously and predominantly an origin zone of international labour migration. The demographic transition implications for both the sending and the new receiving economies of the dynamic Northeast Asian region are to be explored in future studies. 


\section{References}

Athukoralge, P, Chris. M (1999) Structural change and international migration in East Asia: Adjusting to Labour scarcity, Oxford: Oxford University Press

Abella M (1994) Introduction, Asian and Pacific Migration Journal 3(1), Turning Points in Labour Migration: 1-6

1995 'Asian labour migration: past, present and future', ASEAN Economic Bulletin, 12:125-138

Alburo, F.A (1994) "Trade and Turning Points in Labor Migration", Asian and Pacific Migration Journal 3 (1): 49-80

Bade. K Bade K.J \& Oltmer. J (1999) Aussiedler: Deutsche Einwanderer aus Osteuropa, Osnarbrueck: Universitaetsverlag Rasch

Borjas G (1996) Labor Economics, Singapore: McGraw Hill

Bovenkerk F (1974) The Sociology of return migration: a bibliographic essay. Hague: Martinus Nijhoff

Brooks. R and Tao. R (2003) “China's Labour market Performance and Challenges”, IMF (International Monetary Fund) working paper

Castles.S \& Miller.M.J (2003) The age of migration: international population movements in the modern world, London: Macmillan Press

Cho N-H (2000) Policy responses to population and ageing and population decline in Korea from 15. August 2000 Expert group meeting on policy response to population ageing and population decline, UN Population Division

Dietz. B (1995) Zwischen Anpassung und Autonomie: Russlanddeutsche in der Sowjetunion und in der Bundesrepublik Deutschland, Berlin: Duncker \& Humblot

1999 "Ethnic German Immigration from Eastern Europe and the former Soviet Union to Germany: the effects of Migrant Networks, IZADP (Forschungsinstitut zur Zukunft der Arbeit) working paper No.68: Bonn and Hikes.P (1994) Integiert oder isoliert?: Zur Situation russlanddeutscher Aussiedler in der Bundesrepublik Deutschland, Muenchen: Olzog Verlag and Roll.H (1998) Jugendliche Aussiedler- Portraet einer Zuwanderergeneration, Frankfurt, New York: Campus

Fong, P. E (1994) "An Eclectic Approach to Turning Points in Migration", Asian and Pacific Migration Journal 3 (1): 81-91 
Fields, G.S (1994) 'The Migration Transition in Asia' Asian and Pacific Migration Journal 3 (1): 7-30

Fligstein N (1996) 'The Economic Sociology of the Transitions from Socialism', The American Journal of Sociology 101(4): 1074-1081

Fu K. V, Winship.C and Mare.D. R (2004) ‘Sample Selection Bias Models’ in Hardy. M \&

Bryman. A (ed), Handbook of data analysis, London: SAGE, pp. 409-429

Fu Y and Gabriel S. A (2002) "Place-to-Place Migration in China", paper presented at AsRes/AREUEA International Conference, Seoul Korea, July 2002

Ghosh. B (2000) Return migration: journey of hope or despair? Geneva: IOM (International Organisation for Migration)

Guest P (1999) 'Mobility Transitions within a Global System': Migration in the ESCAP Region: Asia-Pacific Population Journal, 14(4): 57-72

Hardy. M and Bryman. A (2004) Handbook of data analysis: London: SAGE

Hu. A (2001) Chapter Six "THE CHINESE ECONOMY IN PROSPECT", RAND corporation Issue Papers: $\underline{\text { Http://www.rand.org/publications/MR/MR1300/MR1300.ch6.pdf }}$

Huw, J (2001) "Reproduction, production, and Migration": The Demographic and Economic Underpinnings of Pacific Asia's Migration, paper presented at Symposium on Immigration Policy in Japan, EU and North America, Kobe Institute Japan, St.Catherine's college: University of Oxford \& Kobe Institute Japan 12-39

International Organisation for Migration (IOM) (2003), Chapter 11 "Driving Forces of Labour migration in Asia" in WORLD MIGRATION REPORT, Geneva: International Organisation for Migration

Iredale R, Guo F and Rozario S (2003) Return Migration in the Asia Pacific. Cheltenham UK \& Northampton MA, USA: Edward Elgar

Joppke.C \& Roshenhek.Z (2001) "Ethnic-priority Immigration in Israel and Germany":

Resilience and demise, CCIS working paper No.45 December 2001, University of California San Diego

Kaiser R (2004) "Homeland making and the territorialisation of national identity" in Coversi. D (Ed) Ethnonationalism in the Contemporary World, London: Routledge

Porters. A, Boerocz. J (1989) Contemporary Immigration: Theoretical Perspectives on its Determinants and Mode of Incorporation, International Migration Review XXIII (3): 607-630. 
Kim Harris (2003) 'Ethnic enclave economy in Urban China: the Korean immigrants in Yanbian', Ethnic and Racial Studies, 26(5): 802-828

King. R (1986) Return migration and regional Economic problems, Kent: Croom Helm

Lin, K.C. (2003) "Corporatizing China: Reinventing State Control for the Market." Doctoral thesis, Department of political science, University of California: Berkeley, CA.

Ministry of Justice, Republic of Korea (immigration bureau) 'Statistical Yearbook of Immigration Control' 1999-2003

Manning C (2001) “The East Asian economic crisis and labour": a setback for international economic integration? Technical Report Working papers in Trade and Development No.2001/03, Economics, RSPAS, ANU.

Martin.P, Mason. A, Nagayama T (1996) Introduction, "The Dynamics of Labour Migration in Asia”, Asian Pacific Migration Journal 5(2-3): 164-173

Massey, D.S (1987) The Ethnosurvey in Theory and Practice, International Migration Review XXI (4): 1498-1522

and Arango J, Hugo G, Kouaouci. A, Pellegrino. A, and Taylor. J.E. (1998) Worlds in Motion: Understanding International Migration at the end of the Millennium, Oxford: Oxford University Press

and Constant. A (2002) Return Migration by German Guest workers: Neo-classical versus New Economic Theories, International Migration 40(4): 5-38

Muenz, R, Ohliger R 2003 Diasporas and Ethnic Migrants: Germany, Israel and Post-Soviet Successor States in Comparative Perspective, London: FRANK CASS PUBLISHERS and Schuck. P.H(ed) 1998 'Long Distance Citizens' in Paths to inclusion: the integration of migrants in the United States and Germany, New York: Berg Hahn Books

Nee. V 1996 'The emergence of a Market Society: Changing Mechanisms of Stratification in China': The American Journal of Sociology, 101(4): 908-948

OECD (Organisation for Economic Co-operation and Development)

SOPEMI's Annual Report, 1999(169-171), 2001(349), 2003(210-213, 368) Trends in international migration Paris: OECD

2001, Migration and Labour Market in Asia, Paris: OECD

Park. Y. B (1994) "The Turning Point in International Labor Migration and Economic Development in Korea." 3 (1): 149-174.

Qian Y (1999) 'The process of China's market Transition (1978-98)': the evolutionary, historical and comparative perspectives, paper prepared for the Journal of Institutional and Theoretical Economics symposium on "Big Bang Transformation of Economics Systems as a Challenge to New Institutional Economics,” June 9-11,1999, Wallerfangen/Saar, Germany 
Robert N, Gwynne, Thomas Klak and Denis J.B. Shaw (2003) Alternative capitalisms: geographies of emerging regions, London: Arnold

Skeldon. R (1990) Population mobility in developing countries: A reinterpretation, London: Belhaven Press 1992 "On Mobility and Fertility Transitions in East Asia and Southeast Asia", Asian and Pacific Migration Journal 1(2): 220-249 1997 Migration and Development: A Global Perspective, Essex: Longman 1999 "Migration in Asia after the Economic Crisis" Asia-Pacific Population Journal 14 (3): 3-24 2001 "The dangers of Diaspora: Orientalism, the Nation State and the search for a new Geopolitical order" in Siddique M.A.B (Ed) International Migration into the $21^{\text {st }}$ Century: Essays in Honour of Reginald Appleyard. Cheltenham: Edward Elgar

Siddique M.A.B (2001) International Migration into the $21^{\text {st }}$ Century: Essays in Honour of Reginald Appleyard. Cheltenham: Edward Elgar

Singer.A, Massey.D (1997) 'The Social Process of undocumented Border Crossing', Lewis Center for Regional Policy Studies, Working Paper No.27

Shuval. J. T (1998) Migration to Israel: The Mythology of Uniqueness, International Migration Quarterly Review 36(1):4-23

Solinger. D (1999) Contesting citizenship in urban China Berkeley, London: University of California Press

Stark.O and Bloom.D.E (1985) "The New Economics of Labour Migration”, American Economic Review 75(2): 173-178

1989 "Relative deprivation and International Migration", Demography 26(1):1-14

1991 The Migration of Labour, Basil Blackwell, Cambridge

2001 Migration Dynamics, Economics Letters 76(2):159-164

Todaro M.P (1996) 'A model of labor migration and urban unemployment in less developed countries’, American Economic Review, 59:138-48.

United Nations 2003 World Urbanization Prospects: the 2003 revision Department of Economic and Social Affairs Population Division, New York: http://www.un.org/esa/population/publications/wup2003/2003WUP.htm

Zelinsky, W (1971) “The Hypothesis of the Mobility”, Geographical Review (61): 219-249

Zhou X (2000) Reply: beyond the debate and toward substantive institutional analysis', American Journal of Sociology, 105(4): 1190-1195 